\title{
19: 56049983-56055832
}

National Cancer Institute

\section{Source}

National Cancer Institute. 19: 56049983-56055832. NCI Thesaurus. Code C45070.

Physical location of KLK3_Gene 